\title{
MONITORING PROPOSAL OF THE EURASIAN WATER SHREW (NEOMYS FODIENS, PENNANT, 1771) IN POLAND
}

Faculty of Animal Breeding, Bioengineering and Conservation, Warsaw University of Life Sciences - SGGW, Warszawa, Poland

\begin{abstract}
The paper presents a proposal of methods for monitoring the Eurasian water shrew Neomys fodiens, belonging to the family Soricidae. This species has a wide range in Poland, although it has never been the subject of a nationwide survey. Water shrew has a sporadic and localised occurrence and little is known about its habitat requirements and population dynamics. Although there is no documented proof of population decline, there is concern that the species may be vulnerable to declines in abundance and occurrence as a result of habitat loss and pollution as it is closely associated with aquatic environment. The proposed method of population status assessment is based on estimating the number of specimen observed at selected monitoring sites by the capture-mark-recapture (CMR) method and an additional method of analysing owl pellets to establish the presence and abundance of the species in the area. Moreover, indicators assessing the condition of the habitat, such as presence of preferred water bodies, share of shoreline vegetation, slope of the shore and availability of shelters have been proposed. Regular monitoring can contribute to the recognition of potential changes in water shrew's population dynamics.
\end{abstract}

Key words: the Eurasian water shrew, Neomys fodiens, monitoring methods, habitat indicators.

\section{INTRODUCTION}

The Eurasian water shrew Neomys fodiens belongs to the family Soricidae, but in contrast to most of the members of the family, this species is very closely associated with water bodies (Rychlik 2000). It is known from almost the whole area of Poland, nevertheless the population trends of it and habitat requirements are poorly known. Like many other small mammal species water shrews have never been a subject to nationwide monitoring and evidence of its occurrence is fragmentary. Although there is no documented proof of population decline, there is a concern that the species may be vulnerable to declines in abundance and occurrence as a result of habitat loss and pollution (Carter and Churchfield 2006). The aim of this study was to propose methods of monitoring of the Eurasian water shrew $N$. fodiens. Proposed methods presented in the paper can contribute to a better knowledge of water shrews populations trends, habitat requirements and the recognition of potential changes in its population dynamics.

Corresponding author: Michalina Gmaj, Faculty of Animal Breeding, Bioengineering and Conservation, Warsaw University of Life Sciences - SGGW, Józefa Ciszewskiego 8, 02-786 Warszawa, Poland, e-mail: michalina.gmaj@gmail.com. 


\section{DESCRIPTION OF THE SPECIES}

The Eurasian water shrew is the largest representative of the shrew family in Poland. The body of water shrew reaches a length of about 7-10 cm and weighs about 7-28 g. It is covered with a dense, velvety, short hair coat that traps air to create insulation when diving (Churchfield 1998). The dorsal side of the animal is dark grey or dark brown, while the ventral side is mostly white, sharply demarcated from the dorsum. The colouration of the belly, however, is individually variable, and there are individuals with dark bellies. There is a white spot just behind the eye, sometimes also near the small, rounded ear, which is hidden in the fur. The head tapers forward into a long snout.

The Eurasian water shrew may be confused with the Southern water shrew Neomys anomalus, which occupies the same habitats (Keckel et al. 2014). The identifying feature of the Eurasian water shrew is its tail, reaching up to $8 \mathrm{~cm}$ in length. Its underside forms the so-called keel - a strip of stiff, bristly hairs that serves as a rudder and additional propulsion during swimming. In the Neomys fodiens case the keel runs the whole length of the tail, in the Neomys anomalus case it occurs from mid-tail onwards. The front feet of the Eurasian water shrew are small and grippy, while the back feet are larger, longer, heavily bristled and covered with stiff, long hairs - they serve as oars (Pucek 1984). A summary of the differences in morphological features between Neomys fodiens and Neomys anomalus is shown in Table 1.

Table 1. The most important morphological features distinguishing the Eurasian water shrew from the Southern water shrew (Pucek 1984)

\begin{tabular}{lll}
\hline \multicolumn{1}{c}{ Morphological features } & \multicolumn{1}{c}{ The Eurasian water shrew } & \multicolumn{1}{c}{ The Southern water shrew } \\
\hline Body weight & $9-25 \mathrm{~g}$ & $6-20 \mathrm{~g}$ \\
Body length & $7-10 \mathrm{~cm}$ & $6-9 \mathrm{~cm}$ \\
Tail hair & keel present at least $2 / 3$ & keel present at least $1 / 2$ \\
of the length of the tail & $<$ the length of the tail \\
Hind foot length & $>16 \mathrm{~mm}$ & $<16 \mathrm{~mm}$ \\
Foot edges & heavily bristed & faintly bristled \\
\hline
\end{tabular}

\section{BIOLOGY OF THE SPECIES}

The Eurasian water shrews are active both day and night, but are known to be more active at night, particularly just after sunset and just before dawn. They are usually solitary and territorial and their density in optimal habitats reaches 3-5 individuals per hectare. The territory of water shrews reaches about 60-80 $\mathrm{m}^{2}$ (Churchfield 1984, 1997).

They dive well and move well in the water. The fur does not soak up with water and is surrounded by a thin layer of air while swimming, insulating the animal's body from excessive cooling. Once out of the water, shrews enter one of their many burrows and the moisture adhering to their fur is absorbed by the walls of the burrow (Churchfield 1984). They dig their burrows in the steep banks of pools, in soft ground, adjacent to water or under tree roots. Water shrews seldom occupy the corridors of moles or rodents for their hiding places. 
They can stay underwater for 5-20 seconds. Water shrews live individually, but the territories of different individuals may overlap (Pucek 1984). They are food opportunists, hunting a wide variety of aquatic and terrestrial prey. The size of prey taken ranges from small aquatic larvae, insects, snails and earthworms to much larger fish, newts, frogs and small rodents (Churchfield 1985). Food captured in the water is consumed on shore. On land, food gathering places (food stores) may be encountered where water shrews hide and gather their prey (Buchalczyk and Pucek 1963).

In capturing and killing prey (even twice its own weight) $N$. fodiens is aided by its venom. Venom is produced by the submandibular salivary glands and is excreted with the saliva. Larger prey is attacked by the animal from behind, trying to damage the back of the head. (Pucek 1959).

They can survive for up to 57 hours without food, their energy requirements being $22 \%$ higher than those of rodents of the same size.

Mating occurs from April to September. Pregnancy lasts 19-20 days. During the year, females give birth to 2-3 litters, each consisting of 3-13 young. The maximum life span of water shrews is estimated at one and a half years (Pucek 1984).

\section{HABITAT REQUIREMENTS}

The species is closely associated with water bodies (Rychlik 2000). It readily inhabits the overgrown banks of rivers, canals, ditches and streams with gravel or sand bottoms, especially if they are rich in rotten stumps and fallen tree logs. It also inhabits lake shores, wet meadows overgrown with shrubs and trees and parts of forests periodically flooded with water (e.g. alder swamps in river valleys). During the migration of young, they can be occasionally found in habitats even far removed from the above biotopes (Pucek 1984; Keckel et al. 2014).

\section{DISTRIBUTION OF THE SPECIES IN POLAND}

In Poland the species is known from almost the whole area of the country, nevertheless the population trends of it is poorly known. Water shrews have never been a subject to nationwide monitoring and evidence of its occurrence is fragmentary. It is abundant only very sporadically and locally in its favoured habitats. The water shrew is habitat-specific and there is concern that it may be declining in numbers and occurrence, particularly in once-favoured sites, as a result of habitat destruction and modification (Churchfield 1997; Carter and Churchfield 2006). Loss of wetland habitats through drainage, conversion to agricultural land, and destruction of natural vegetation at the water's banks may pose a threat to the Eurasian water shrew. It may suffer from a shortage of food when prey species decline owing to acidification and pollution of water with pesticides, fertilisers, and sewage (Spitzenberger 1999). 


\section{CONCEPT OF THE SPECIES MONITORING}

The proposed method of population monitoring of water shrew described in this paper is based on estimating the number of specimen observed at selected study plots (monitoring sites) by the capture-mark-recapture (CMR) method. Additional method based on the analysis of owl pellets is proposed to establish the presence and abundance of the species in the area.

Monitoring method includes also the evaluation of the status of the natural habitat in monitoring locations. Monitoring of habitat condition involves the study of those elements of the environment that determine its quality in terms of the requirements of the species. The selection of habitat characteristics assessed in the monitoring was based on available data on the habitat preferences of the water shrew, obtained from both polish and international publications (Pucek 1984; Keckel et al. 2014).

The proposed trapping methodology is consistent with that used to survey shrews (Churchfield 1984; Greenwood et al. 2002) and aims to increase trapping efficiency and minimise animal mortality. It may be difficult to differentiate between the Eurasian water shrew and the Southern water shrew in areas where both species occur simultaneously, but the previously mentioned morphological characteristics (keel length, feet, body size) allow these species to be distinguished from each other during trapping.

\section{INDICATORS}

\section{Population}

The indicator for population status is the number of individuals per 100 trap-nights caught at the site. It is obtained by multiplying the total number of specimens caught by 100 and dividing by the number of trapping days multiplied by the number of traps used. This standardisation of the abundance index allows comparison between years and between sites, taking into account differences in trapping duration and number of traps used. The number of traps used depends on the plot size and habitat diversity, but should not be less than 20 traps per ha.

The assessment system is taken from the Methodology of nature monitoring (Makomaska-Juchiewicz 2015). Indicator of the population's state is shown in Table 2.

Table 2. Indicator of the state of population of the Eurasian water shrew

\begin{tabular}{cll}
\hline Indicator & Measurement & Way of evaluation \\
\hline Population density & $\begin{array}{l}\text { number of } \\
\text { individuals } / 100 \\
\text { trap-nights }\end{array}$ & $\begin{array}{l}\text { The average density of specimens calculated on the } \\
\text { basis of the results of catches using the CMR method } \\
\text { at monitoring sites }\end{array}$ \\
\hline
\end{tabular}

Adopted valorization of the status indicator of the population is presented in Table 3. 
Table 3. Valorization of the Eurasian water shrew population status indicator

\begin{tabular}{|c|c|c|c|}
\hline \multirow{2}{*}{ Indicator } & \multicolumn{3}{|c|}{ Evaluation* } \\
\hline & FV & U1 & U2 \\
\hline Population density & $>2.5$ individual/ha & $0-2.5$ individual/ha & 0 \\
\hline
\end{tabular}

* FV - favourable, U1 - unfavourable-inadequate, U2 - unfavourable-bad.

\section{Habitat}

Indicators of the habitat are shown in Table 4.

Table 4. Indicators of the habitat of the Eurasian water shrew

\begin{tabular}{|c|c|c|}
\hline Indicator & Measurement & Way of evaluation \\
\hline $\begin{array}{l}\text { Presence of preferred water } \\
\text { bodies }\end{array}$ & $\%$ & $\begin{array}{l}\text { Percentage of monitoring points at which, or in the vicinity } \\
\text { of which within } 20 \mathrm{~m} \text { of the designated survey area, the presence } \\
\text { of preferred types of water bodies was recorded }\end{array}$ \\
\hline $\begin{array}{l}\text { Share of shoreline } \\
\text { vegetation }\end{array}$ & $\%$ & $\begin{array}{l}\text { Estimated proportion of the reservoir shoreline covered by } \\
\text { herbaceous vegetation, shrubs, rushes }\end{array}$ \\
\hline Slope of the shore & $\circ$ & Slope of the shoreline towards the water expressed in degres \\
\hline Availability of shelters & $\%$ & $\begin{array}{l}\text { Proportion of monitoring points recording the presence of habitats } \\
\text { suitable for shelter for water shrews }\end{array}$ \\
\hline
\end{tabular}

Valorization of the habitat state are shown in Table 5.

Table 5. Evaluation of indicators of the habitat of the Eurasian water shrew

\begin{tabular}{|c|c|c|c|}
\hline \multirow{2}{*}{ Indicator } & \multicolumn{3}{|c|}{ Evaluation* } \\
\hline & FV & U1 & U2 \\
\hline $\begin{array}{l}\text { Presence of preferred } \\
\text { water bodies }\end{array}$ & $>70 \%$ & $70-40 \%$ & $<40 \%$ \\
\hline $\begin{array}{l}\text { Share of shoreline } \\
\text { vegetation }\end{array}$ & $60-100 \%$ & $20-60 \%$ & $<20 \%$ \\
\hline Slope of the shore & $>40^{\circ}$ & $20-40^{\circ}$ & $<20^{\circ}$ \\
\hline
\end{tabular}

* FV - favourable, U1 - unfavourable-inadequate, U2 - unfavourable-bad.

The assessment of habitat condition in the area is determined by the lowest of the four indices. 


\section{Conservation prospects}

Assessment by an expert taking into account the current state of the population and the state of the habitat, observed negative impacts and threats:

FV - good prospects. Population data and favourable habitat conditions indicate that the population will expand or maintain itself at least at the same level for the foreseeable future.

U1 - unfavourable-inadequate prospects. The population is declining or there is a likelihood of habitat deterioration.

U2 - bad prospects. Population and habitat conditions are poor or likely to deteriorate significantly.

Threats facing the species are mainly the loss of wetland habitats due to drainage, conversion to agricultural land and destruction of natural vegetation on the banks of water bodies; pollution of water with pesticides, fertilisers and sewage, which reduces the amount of food in the environment (Spitzenberger 1999).

\section{GENERAL EVALUATION}

The overall assessment takes into account the assessment of all three parameters (population, habitat, conservation prospects). The overall assessment corresponds to the lowest of these parameters.

\section{THE METHOD OF MONITORING SURVEYS}

\section{Selection of monitoring plots and their suggested size}

In the case of water shrew, a monitoring plot (site) is an area where trapping is carried out. During one season, trapping should be carried out on about 20 plots throughout the range of the species and should cover a variety of habitats (river banks, lakes, canals, wet meadows, alder swamps).

A monitoring plot should consist of at least three transects parallel to a water body, 10-20 points in each line. The first line is a transect running directly to the water's edge, the second line - at a distance of $2 \mathrm{~m}$ and the third line - 10-20 m from the edge. The distance between adjacent points in one line should be approximately $20 \mathrm{~m}$. The size of the smallest monitoring area shall correspond to the area determined by the most distant traps (not less than $0.5 \mathrm{ha}$ ).

\section{Determination of population status indicators - trapping}

Monitoring should be based on the method of CMR (Capture-Mark-Recapture). This consists of catching animals in baited traps, species identification, non-permanently marking and releasing at the site of capture. Non-permanent marking involves dotting the tail with a white, animal-safe marker. This method is not invasive and does not require special permissions from Local Ethical Committee for Animal Experiments. The method of hair trimming was not chosen because of the important role that water shrew's fur plays in swimming and diving. 
For trapping it is suggested to use commonly used cage type live traps, e.g. Sherman and cones, cylinders buried in the ground.

It is recommended:

- recording the location of traps;

- provision of high-energy food in traps (e.g. ground beef);

- providing bedding for thermal insulation (e.g. dry hay);

- checking traps at least every 4 hours; at each inspection, checking the level and condition of bedding and food;

- covering the cage traps with surrounding vegetation or other items to insulate them from extreme temperatures;

- protection of cones and cylinders buried in the ground by a roof to prevent flooding during rain.

These methods have been shown to prevent unnecessary deaths of shrews due to freezing, starvation and dehydration and contribute to reducing stress-related mortality (Rychlik et al. 2012; Shonfield et al. 2013).

As the Eurasian river shrew is a partially protected species in Poland, a permit from the Regional Director of Environmental Protection is required for its capture.

\section{Determination of Population Status Indicators - analysis of owl pellets}

Analyses of owl pellets can offer an alternative source of data on the abundances and local distributions of water shrews. The easiest to obtain and relatively simple in analyses are the tawny owl Strix aluco pellets, the species that can breed in various habitats and is a dietary generalist. The tawny owl is a non-migratory, territorial species which implies that all prey items found in their pellets will have been caught within a few hundred meters of the breeding site (Gryz and Krauze 2007). Pellets are easiest to find in early spring, before the development of undergrowth. They should be collected regularly, at least once every six months. Otherwise the pellets remaining in the field will be partially decomposed, making it difficult to determine the number of prey and their species identification. The collected pellets should be packed separately in envelopes and labelled with the place and date of collection. The collected material should be subjected to analysis as soon as possible or, if necessary, frozen or dried. Based on the number of right and left jaws it is possible to determine the number of specimens of a given species in a pellet. Other owl species that can be used in water shrew monitoring is barn owl Tytus alba, which usually nest in buildings, attics and barns, therefore their pellets are readily accessible.

Sites for the search of owl pellets should be located as close as possible to areas suitable for the Eurasian water shrew, i.e. areas associated with aquatic habitats. When searching for potential collection sites, it is suggested to use an information from local ornithologists or residents, who are often able to identify owl sites. The Key to the Identification of Mammals of Poland by Pucek (1984) can be used to identify mammal remains.

\section{Date and frequency of surveys}

Trapping water shrews should be carried out in July-September period when the population is at its peak. Weather conditions are important and may also affect the shrew's mortality. Monitoring studies are best carried out annually in order to obtain the information about 
changes in the population. However, if not possible, the period between the surveys shouldn't exceed 3 years, considering short life span and natural fluctuations in population size of water shrews.

\section{Species with similar ecological requirements for which the methodology can be adapted}

A species with similar ecological requirements, mentioned several times in the paper, for which the above-mentioned monitoring methods can be applied is the Southern water shrew. This species inhabits very similar habitats only exhibits less dependence on proximity to water bodies.

\section{CONCLUSIONS}

Regular monitoring can contribute to the recognition of potential changes in water shrew's population dynamics. The data obtained as a result of the proposed monitoring methods can contribute to a better knowledge of $N$. fodiens populations trends and habitat requirements.

\section{REFERENCES}

Buchalczyk T., Pucek Z. 1963. Food storage of the European water shrew, Neomys fodiens (Pennant, 1771). Acta Theriol. 7(19), 376-379.

Carter P., Churchfield S. 2006. The Water Shrew Handbook. London, The Mammal Society.

Churchfield S. 1984. An investigation of the population ecology of syntopic shrews inhabiting watercress beds. J. Zool. 204, 229-240.

Churchfield S. 1985. The feeding ecology of the European Water shrew. Mamm. Rev. 15(1), 13-21.

Churchfield S. 1997. Management guidelines: water shrew (Neomys fodiens). Environment Agency species and habitats handbook. Bristol, The Environment Agency (EA).

Churchfield S. 1998. Habitat use by water shrews, the smallest of amphibious mammals, in: Behaviour and Ecology of Riparian Mammals (Symposia of the Zoological Society of London). Eds. N. Dunstone, M. Gorman. Cambridge, Cambridge University Press, 49-68.

Greenwood A., Churchfield S., Hickey C. 2002. Geographical distribution and habitat occurrence of the Water Shrew Neomys fodiens in the Weald of South-East England. Mamm. Rev. 32(1), 40-50.

Gryz J., Krauze D. 2007. Analysis of owl pellets as noninvasive method of finding rare species of mammals. Stud. Mat. CEPL 9(16), 431-437.

Keckel M.R., Ansorge H., Stefen C. 2014. Differences in the microhabitat preferences of Neomys fodiens (Pennant 1771) and Neomys anomalus Cabrera, 1907 in Saxony, Germany. Acta Theriol. 59, 485-494.

Makomaska-Juchiewicz M., Bonk M. (ed.) 2015. Monitoring gatunków zwierząt. Przewodnik metodyczny. Część IV. Warszawa, GIOŚ. [in Polish]

Pucek M. 1959. The effect of the venom of the European water shrew (Neomys fodiens fodiens Pennant) on certain experimental animals. Acta. Theriolog. 3, 93-104.

Pucek Z. 1984. Klucz do oznaczania ssaków Polski. Warszawa, PWN. [in Polish]

Rychlik L. 2000. Habitat preferences of four sympatric species of shrews. Acta Theriol. 45, 173-190.

Rychlik L., Churchfield S., Taylor J., Kardynia P., Ołdakowski Ł. 2012. Live-trapping small mammals under snow: A protocol for maximising captures and minimising mortality. Pol. J. Ecol. 60, 621-628.

Shonfield J., Do R., Brooks R.J., McAdam A.G. 2013. Reducing accidental shrew mortality associated with small-mammal livetrapping I: An inter- and intrastudy analysis. J. Mamm. 94(4), 745-753. 
Spitzenberger F. 1999. Neomys fodiens (Pennant, 1771) \& Neomys anomalus Cabrera, 1907, in: Atlas of European Mammals. Eds. A.J. Mitchell-Jones, G. Amori, W. Bogdanowicz, B. Kryštufek, P.J. Reijnders, F. Spitzenberger, M. Stubbe, J.B. Thissen, V. Vohralik, J. Zima. London, The Academic Press, 496.

\title{
PROPOZYCJA MONITORINGU RZĘSORKA RZECZKA (NEOMYS FODIENS, PENNANT, 1771) W POLSCE
}

\begin{abstract}
Streszczenie. W pracy przedstawiono propozycję metod monitoringu rzęsorka rzeczka (Neomys fodiens), należącego do rodziny ryjówkowatych (Soricidae). Mimo iż gatunek ten ma szeroki zasięg występowania w Polsce, nigdy nie był przedmiotem ogólnopolskich badań. Rzęsorek rzeczek występuje sporadycznie i lokalnie, niewiele wiadomo o jego wymaganiach siedliskowych i dynamice populacji. Chociaż nie udokumentowano spadku liczebności populacji rzęsorka, istnieje obawa, że gatunek ten może być narażony w wyniku utraty siedlisk i zanieczyszczenia środowiska wodnego, z którym jest ściśle związany. Zaproponowana metoda oceny stanu populacji opiera się na szacowaniu liczby osobników obserwowanych na wybranych stanowiskach monitoringowych metodą wielokrotnego odławiania, znakowania i wypuszczania (CMR) oraz dodatkowej metodzie analizy wypluwek sów, w celu ustalenia obecności i liczebności populacji gatunku na danym obszarze. Ponadto zaproponowano wskaźniki oceniające stan siedliska, takie jak obecność preferowanych zbiorników wodnych, udział roślinności brzegowej, nachylenie brzegu i dostępność schronień. Regularny monitoring może przyczynić się do rozpoznania potencjalnych zmian $\mathrm{w}$ dynamice populacji rzęsorka rzeczka.
\end{abstract}

Słowa kluczowe: rzęsorek rzeczek, Neomys fodiens, metody monitoringu, wskaźniki stanu siedliska. 
